\title{
José Helder Teixeira
}

O homenageado desta edição é o psicólogo José Helder Teixeira. Zé Helder, como era chamado pelos amigos, era formado em Psicologia, com pós-graduação em psicodrama e mestrado em Saúde Mental pela Pontifícia Universidade Católica de Goiás (1995). Trabalhou na Secretaria Estadual de Educação, em Goiânia-GO, ministrando aulas de Psicologia e saúde mental para alunos do ensino básico e técnicos de enfermagem no Colégio Universitário - COLU e para a Escola Profissionalizante do SENAC.

Militante do Fórum Goiano de Saúde Mental e concursado pela Secretaria Municipal de Saúde de Goiânia, José Helder participou da implantação do primeiro Centro de Atenção Psicossocial de Goiânia, o CAPS Novo Mundo (2000). Com uma vasta experiência em saúde mental, implantou e foi coordenador técnico do CAPS Vida (2003). Também atuou na Diretoria de Atenção à Saúde da Secretaria Municipal de Saúde (2009).

Citado por amigos como uma pessoa inquieta e estudiosa, José Helder esteve envolvido em diversas frentes, entre elas, na implantação e coordenação do projeto Humanização do Município, em Goiânia (2001), no qual formava equipes de acolhimento a pessoas com suspeita de dengue nos Centros de Saúde. Na época, a cidade vivia uma epidemia da doença, e a população pouco frequentava as unidades de saúde. Então, Helder e outros psicólogos começaram o projeto, que tinha como objetivo orientar a população sobre a importância de irem às unidades de saúde fazer o tratamento.

José foi eleito conselheiro no V e VI Plenários do CRP-09 (GO) (2004-2010), atuando como presidente da Comissão de Ética. Sua passagem pelo Conselho Regional foi marcada por profundo respeito ao ser humano, à diversidade e à ética na profissão.

Zé Helder foi descrito pelos amigos como uma pessoa calma, sorridente e de fala mansa, que sempre surpreendeu os colegas com sua bondade e sua dedicação intensa ao trabalho, ao amor e à família.

O psicólogo faleceu em 28 de julho de 2011, deixando um casal de filhos e muitos amigos e colegas de trabalho que reconheceram sua dedicação profissional, ética e sensibilidade. 